University of Nebraska - Lincoln

DigitalCommons@University of Nebraska - Lincoln

Faculty Publications: Agricultural Leadership, Education \& Communication Department
Agricultural Leadership, Education \&

Communication Department

4-9-2004

\title{
Short and Long-Term Impacts of Biotechnology Education on Professionals Who Communicate Science to the Public
}

\author{
Susan Fritz \\ University of Nebraska - Lincoln, sfritz1@unl.edu \\ Sarah M. Ward \\ Colorado State University \\ Pat F. Byrne \\ Colorado State University, Patrick.Byrne@ColoState.edu \\ Deana Namuth \\ University of Nebraska - Lincoln, dnamuth1@unl.edu \\ Valerie Egger \\ vegger1@unl.edu
}

Follow this and additional works at: https://digitalcommons.unl.edu/aglecfacpub

Part of the Other Public Affairs, Public Policy and Public Administration Commons

Fritz, Susan; Ward, Sarah M.; Byrne, Pat F.; Namuth, Deana; and Egger, Valerie, "Short and Long-Term Impacts of Biotechnology Education on Professionals Who Communicate Science to the Public" (2004). Faculty Publications: Agricultural Leadership, Education \& Communication Department. 34.

https://digitalcommons.unl.edu/aglecfacpub/34

This Article is brought to you for free and open access by the Agricultural Leadership, Education \& Communication Department at DigitalCommons@University of Nebraska - Lincoln. It has been accepted for inclusion in Faculty Publications: Agricultural Leadership, Education \& Communication Department by an authorized administrator of DigitalCommons@University of Nebraska - Lincoln. 


\title{
Short and Long-Term Impacts of Biotechnology Education on Professionals Who Communicate Science to the Public
}

\author{
Susan M. Fritz, * Sarah M. Ward, Pat F. Byrne, Deana M. Namuth, and Valerie A. Egger
}

\begin{abstract}
Consumer acceptance or rejection of biotechnology is often shaped by information prepared by communicators with varying levels of scientific knowledge, awareness, and acceptance. This study compared the prior, post-workshop, and sustained (1 year) biotechnology awareness, acceptance, and attitudes of professionals who communicate biotechnology to the public at an informational, day-long, university-sponsored workshop. Thirty-seven participants completed the three rounds of data collection. They consistently rated their scientific knowledge high. Throughout the three rounds, their primary media source of biotechnology information was newspapers, with the web being the second most frequently cited source. Participants were somewhat accepting of genetic modification of microorganisms, forests/landscape plants, and food crops, but were somewhat unaccepting of genetic modification of animals and humans. Fear of genes moving unchecked to other plants, insects, or microorganisms; fear of environmental harm; and fear of food safety consequences were identified as obstacles to their acceptance of food biotechnology. Participants were most confident with statements related to biotechnology from university scientists and health professionals and least confident with statements from celebrities. They saw their professional role in providing analysis and interpretation regarding desirable and undesirable consequences of biotechnology as important. Although the study participants were professionals, their awareness and attitudes toward biotechnology were similar to consumer awareness and attitudes measured in previous studies. It is important that university scientists provide unbiased, research-based biotechnology information to those who communicate biotechnology to the public (e.g., through workshops, websites, etc.) and accommodate learners with varying levels of scientific knowledge, because these communicators will affect consumer attitudes.
\end{abstract}

S.M. Fritz and V.A. Egger, Dep. of Agricultural Leadership, Education and Communication, $300 \mathrm{Ag}$ Hall, Univ. of Nebraska-Lincoln, Lincoln, NE 68583; S.M. Ward and P.F. Byrne, Dep. of Soil and Crop Sciences, Colorado State Univ., Fort Collins, CO 80523-1170; and D.M. Namuth, Dep. of Agronomy and Horticulture, 279 Plant Science, Univ. of Nebraska-Lincoln, Lincoln, NE 68583. Partial funding received from USDA CSREES IFAFS support, grant no. 00-52100-9710. University of Nebraska-Lincoln College of Agricultural Sciences and Natural Resources Journal Series no. 03-14. Received17 Sept. 2003.

*Corresponding author (sfritz1@unl.edu).

Copyright (C) 2004 by the American Society of Agronomy, 677 S. Segoe Rd., Madison, WI 53711 USA

At the request of the American Society of Agronomy, full text of this paper is not archived here; a copy may be accessed from the Society's site at :

http://www.jnrlse.org/pdf/2004/E03-26.pdf 